\title{
EFFECTS OF 6-WEEK PRE-SEASON PLYOMETRIC TRAINING TO PERFORMANCE CHARACTERISTICS IN FEMALE HANDBALL PLAYERS
}

\author{
Mehmet Kale \\ Anadolu University, Faculty of Sports Science, Department of Coaching, Eskisehir, Turkey
}

\begin{abstract}
The purpose of this study was to examine the effects of a 6-week pre-season plyometric training on the performance characteristics in female handball players. Nineteen female handball players voluntarily participated in the study. They were divided into 2 groups [experimental group (ETG; $N=10$ ), and control group (NTG; $N=9$ )]. Both groups continued regular pre-season training for 6-weeks. The ETG also did plyometric training. Sprints (10 m, $20 \mathrm{~m}$, and $30 \mathrm{~m})$, squat jump (SJ), countermovement jump (CMJ), anaerobic power and capacity (AP and AC), and aerobic variables at fixed blood lactate levels (FBLLs) [running velocity (RV), heart rate (HR), and oxygen consumption $\left(\mathrm{VO}_{2}\right)$ ] were compared before and after the training. The results have shown that there are significant differences in $S J$ and $C M J(p<0.05)$, all sprints $(\mathrm{p}<0.01), \mathrm{AP}$ and $\mathrm{AC}(\mathrm{p}<0.05), \mathrm{VO}_{2} \max (\mathrm{p}<0.01), \mathrm{RV}, \mathrm{HR}$, and $\mathrm{VO}_{2}$ at each of FBLLs $(\mathrm{p}<0.01)$ between pre- and post-training results of ETG. Pre- and post training results also showed significant differences in SJ and CMJ $(\mathrm{p}<0.05)$, all sprints $(\mathrm{p}<0.01)$, and AP $(\mathrm{p}<0.05)$ in NTG. In conclusion, was found that a 6-week plyometric training is an important parameter in addition to physical fitness, technical, and tactical training for the female handball players who get prepared for the woman handball super league which affects pre-season performance charecteristics.
\end{abstract}

Keywords: PLYOMETRIC TRAINING / JUMP / SPRINT / FIXED BLOOD LACTATE LEVEL

\section{INTRODUCTION}

Handball is one of the sporting activities involving a great amount of body contact among players and various lower extremity movements such as starts, stops, jumps, landings, rapid changes in moving directions, repeated accelerations, and sprints, which provoke high mechanical stress on lower extremity due to high ground reaction forces and different upper extremity movements like throwing, fall landings, and ball blocks (Vicente-Rodrigueza, Doradoa, Perez-Gomeza, Gonzalez-Henriquezbi, \& Calbet, 2004; Ronglan, Raastad, \& Børgese, 2006; Cavala, \& Katic, 2010; Massuca, Fragoso, \& Teles, 2014; Karcher, \& Bucheit, 2014; Wagner, Finkenzeller, Wurth, \& von Duvillard, 2014). These movements put a lot of strain on different muscles and develop degrees of fatigue, which entails a certain amount of recovery time to re- store normal performance level (Ronglan et al, 2006). Handball players who are exposed to heavy load in training should present high levels of strength, muscle power, sprint and endurance running (Granados, Izquierdo, Ibanez, Bonnabau, \& Gorostiaga, 2007). It has been shown that handball performance can be improved by specific handball conditioning with complex resistance, sprint, and endurance training in addition to technical training (Jensen, Jacobsen, Hetland, \& Tveit, 1997). Complex training is necessary for rapid, explosive and powerful muscle contraction ability for handball players. Adaptations to these complex trainings are total changes as a result of regular workouts. However, optimal way and the relative effects of specific training for performance are little known. Gorostiaga et al (Gorostiaga, Granados, Ibanez, Gonzalez-Badillo, \& Izquierdo, 2006) have found significant relationships between muscle 
power output of the upper and lower body extremities related to strength training and high-intensity endurance training during the full training season in elite handball players. Examination of training effect could be of a great importance for the optimal construction of the physical and sport-specific conditioning programs to improve handball performance (Jensen et al., 1997). When physical conditioning, technical and tactical practices in handball are good enough to provide adequate stimuli, particularly for muscle strength enhancement, physical performance could be improved in women handball players. Physiological and bio-motor characteristics are specified and training programs are planned with respect to these characteristics in the scope of these training programs utilizing sports performance tests in track and laboratory conditions.

It is possible to determine physiological changes reasoning by plyometric training, to identify physical status of athletes after plyometric training, and to revise the performance status of athletes having potential for a new training phase. Evaluation of sprint, jump, anaerobic power-capacity, and muscular strength reveal important details about training status of women handball players. From this point, there were no studies investigating handball conditioning parameters monitored over the training phases and the quantitative assessments of training and competition in elite female handball players. Therefore, the aim of this study was to examine the effects of a 6-week pre-season plyometric training on the performance characteristics in female handball players.

\section{MATERIALS AND METHODS}

\section{Participants}

Nineteen-female handball players from the Super Laegue Team voluntarily participated in the study. All subjects performed regular strength/power training at least three times a week for a minimal period of 4-years. They were divided into ETG (age: $20.4 \pm 3.0$ years, height: $170.7 \pm 5.5 \mathrm{~cm}$, weight: $65.8 \pm 8.3 \mathrm{~kg}$ ) and NTG (age: $19.4 \pm 3.3$ years, height: $172.6 \pm 3.9 \mathrm{~cm}$, weight: $66.6 \pm 9.1 \mathrm{~kg}$ ). A written informed consent was obtained from each subject to participate in the study in accordance with the ethical standards of the Helsinki Declaration. The study was approved by the Ethical Committee of Osmangazi University.

\section{Procedures}

Each player was tested at the beginning and end of the pre-season as pre- and post-tests after the laboratory and track visits for 45-60 min of each test at a specific time (16:00-17:00) of days on four occasions to complete familiarization and main trials. Players took part in tests including sprints $(10 \mathrm{~m}, 20 \mathrm{~m}, 30$ $\mathrm{m})$, vertical jumps (SJ, CMJ), anaerobic power-capacity, and aerobic endurance [RV, $\mathrm{HR}, \mathrm{VO}_{2}$ of FBLLs at 2.0 mM.L ${ }^{-1}$ (regeneration) (AE1), 3.0 mM.L ${ }^{-1}$ (intensive tempo) (AE2), $4.0 \mathrm{mM} . \mathrm{L}^{-1}$ (extensive interval) (AE3), 5.0 mM.L ${ }^{-1}$ (intensive interval) (AE4)] in a random order.

\section{Training Period}

Both groups were trained for 6-weeks in physical fitness, technical training (TE) and tactical training (TA), and training game (TG) for the pre-season (Table 1). Each week included 5 training days and 2 rest days on Wednesday and Sunday. Each training day included a 2-hour morning session and a 2-hour evening session. Each session started with $15 \mathrm{~min}$ warm-up including self-paced running, calisthenics, and flexibility exercises and ended up with $10 \mathrm{~min}$ cool-down including self-paced running and flexibility exercises. ETG group performed additional plyometric training [4 exercises (hurdle jumps, lateral multi jumps for plantar flexors and leg extensors, and frontal multi jumps) of 3 sets of 12 reps]. The rest of 30-40 s was allowed between exercises and $3 \mathrm{~min}$ between sets. The exercises were integrated in the first and fourth days on the each training week to allow for sufficient recovery between workouts as recommended by researchers Adams et al (Adams, O'Shea, O'Shea, \& Climstein, 1992). 
Table 1. Training components of 6-week pre-season

\begin{tabular}{|c|c|c|c|c|c|c|c|c|}
\hline \multirow[t]{2}{*}{ Week } & \multirow[t]{2}{*}{ Session } & \multicolumn{7}{|c|}{ Day } \\
\hline & & 1 & 2 & 3 & 4 & 5 & 6 & 7 \\
\hline \multirow[t]{2}{*}{1} & $\mathrm{AM}$ & $\mathrm{S} 1, \mathrm{~W} 1, \mathrm{~A} 1_{10}$ & $\mathrm{~S} 2, \mathrm{~W} 3, \mathrm{Al}_{10}$ & $\mathrm{R}$ & $\mathrm{S} 1, \mathrm{~W} 4, \mathrm{~A} 1_{10}$ & $\mathrm{~S} 2, \mathrm{~W} 2, \mathrm{~A} 4_{1}, \mathrm{~A} 1_{10}$ & $\mathrm{R}$ & $\mathrm{R}$ \\
\hline & $\mathrm{PM}$ & $\mathrm{TE}_{60}, \mathrm{~A} 2_{15}$ & $\mathrm{TE}_{60}, \mathrm{~A}_{4}$ & $\mathrm{R}$ & $\mathrm{TE}_{60}, \mathrm{~A} 2_{20}$ & $\mathrm{TE}_{30}, \mathrm{Al}_{15}$ & TG & $\mathrm{R}$ \\
\hline \multirow[t]{2}{*}{2} & $\mathrm{AM}$ & $\mathrm{S} 1, \mathrm{~W} 1, \mathrm{~A} 1_{10}$ & $\mathrm{~S} 2, \mathrm{~W} 3, \mathrm{~A} 1_{10}$ & $\mathrm{R}$ & $\mathrm{S} 1, \mathrm{~W} 4, \mathrm{~A} 1_{10}$ & $\mathrm{~S} 2, \mathrm{~W} 2, \mathrm{~A} 4_{2}, \mathrm{~A} 1_{10}$ & $\mathrm{R}$ & $\mathrm{R}$ \\
\hline & $\mathrm{PM}$ & $\mathrm{TE}_{60}, \mathrm{~A} 2_{20}$ & $\mathrm{TE}_{60}, \mathrm{~A} 3_{5}$ & $\mathrm{R}$ & $\mathrm{TE}_{60}, \mathrm{~A} 2_{25}$ & $\mathrm{TE}_{30}, \mathrm{~A} 1_{15}$ & TG & $\mathrm{R}$ \\
\hline \multirow[t]{2}{*}{3} & $\mathrm{AM}$ & $\mathrm{S} 1, \mathrm{~W} 1, \mathrm{~A} 1_{10}$ & $\mathrm{~S} 2, \mathrm{~W} 3, \mathrm{~A} 1_{10}$ & $\mathrm{R}$ & $\mathrm{S} 1, \mathrm{~W} 4, \mathrm{~A} 1_{10}$ & $\mathrm{~S} 2, \mathrm{~W} 2, \mathrm{~A} 4_{3}, \mathrm{~A} 1_{15}$ & $\mathrm{R}$ & $\mathrm{R}$ \\
\hline & $\mathrm{PM}$ & $\mathrm{TE}_{60}, \mathrm{~A} 2_{25}$ & $\mathrm{TE}_{60}, \mathrm{~A}_{6}$ & $\mathrm{R}$ & $\mathrm{TE}_{60}, \mathrm{~A} 2_{30}$ & $\mathrm{TE}_{30}, \mathrm{Al}_{15}$ & TG & $\mathrm{R}$ \\
\hline \multirow[t]{2}{*}{4} & $\mathrm{AM}$ & $\mathrm{S} 1, \mathrm{~W} 1, \mathrm{Al}_{10}$ & $\mathrm{~S} 2, \mathrm{~W} 3, \mathrm{~A} 1_{10}$ & $\mathrm{R}$ & $\mathrm{S} 1, \mathrm{~W} 4, \mathrm{Al}_{10}$ & $\mathrm{~S} 2, \mathrm{~W} 2, \mathrm{~A} 4_{1}, \mathrm{~A} 1_{10}$ & $\mathrm{R}$ & $\mathrm{R}$ \\
\hline & $\mathrm{PM}$ & $\mathrm{TE}_{60}, \mathrm{~A} 2_{15}$ & $\mathrm{TE}_{60}, \mathrm{~A}_{4}$ & $\mathrm{R}$ & $\mathrm{TE}_{60}, \mathrm{~A}_{20}$ & $\mathrm{TE}_{30}, \mathrm{Al}_{15}$ & TG & $\mathrm{R}$ \\
\hline \multirow[t]{2}{*}{5} & $\mathrm{AM}$ & $\mathrm{S} 1, \mathrm{~W} 1, \mathrm{~A} 1_{10}$ & $\mathrm{~S} 2, \mathrm{~W} 3, \mathrm{~A} 1_{10}$ & $\mathrm{R}$ & $\mathrm{S} 1, \mathrm{~W} 4, \mathrm{~A} 1_{10}$ & $\mathrm{~S} 2, \mathrm{~W} 2, \mathrm{~A} 4_{2}, \mathrm{~A} 1_{10}$ & $\mathrm{R}$ & $\mathrm{R}$ \\
\hline & $\mathrm{PM}$ & $\mathrm{TE}_{60}, \mathrm{~A} 2_{20}$ & $\mathrm{TA}_{60}, \mathrm{~A}_{5}$ & $\mathrm{R}$ & $\mathrm{TE}_{60}, \mathrm{~A}_{25}$ & $\mathrm{TA}_{30}, \mathrm{Al}_{15}$ & TG & $\mathrm{R}$ \\
\hline \multirow[t]{2}{*}{6} & $\mathrm{AM}$ & $\mathrm{S} 1, \mathrm{~W} 1, \mathrm{~A} 1_{10}$ & $\mathrm{~S} 2, \mathrm{~W} 3, \mathrm{~A} 1_{10}$ & $\mathrm{R}$ & $\mathrm{S} 1, \mathrm{~W} 4, \mathrm{~A} 1_{10}$ & $\mathrm{~S} 2, \mathrm{~W} 2, \mathrm{~A} 4_{3}, \mathrm{~A} 1_{15}$ & $\mathrm{R}$ & $\mathrm{R}$ \\
\hline & $\mathrm{PM}$ & $\mathrm{TE}_{60}, \mathrm{~A} 2_{25}$ & $\mathrm{TA}_{60}, \mathrm{~A} 3_{6}$ & $\mathrm{R}$ & $\mathrm{TA}_{60}, \mathrm{~A} 2_{30}$ & $\mathrm{TA}_{30}, \mathrm{Al}_{15}$ & TG & $\mathrm{R}$ \\
\hline
\end{tabular}

Training program: set $\mathrm{x}$ (set $\mathrm{x}$ repetition)

Aerobic training

$\mathrm{A} 1_{10}: 10 \mathrm{~min}, \mathrm{~A} 1_{15}: 15 \mathrm{~min}$

$\mathrm{A} 2_{15}: 15 \mathrm{~min}, \mathrm{~A} 2_{20}: 20 \mathrm{~min}, \mathrm{~A} 2_{25}: 25 \mathrm{~min}, \mathrm{~A} 2_{30}: 30 \mathrm{~min}$

$\mathrm{A} 33_{4}: 2 \mathrm{x}(2 \times 4 \mathrm{~min}), \mathrm{A}_{5}: 2 \mathrm{x}(2 \times 5 \mathrm{~min}), \mathrm{A} 3_{6}: 2 \mathrm{x}(2 \times 6 \mathrm{~min})$

$\mathrm{A} 4_{1}: 2 \mathrm{x}(2 \times 1 \mathrm{~min}), \mathrm{A}_{2}: 2 \mathrm{x}(2 \times 2 \mathrm{~min}), \mathrm{A} 4_{3}: 2 \mathrm{x}(2 \times 3 \mathrm{~min})$

$\mathrm{TE}_{30}: 30 \mathrm{dk}, \mathrm{TE}_{60}: 60 \mathrm{dk}$

$\mathrm{TA}_{30}: 30 \mathrm{dk}, \mathrm{TA}_{60}: 60 \mathrm{dk}$

Speed training

S1 (SPEED1):Sprint ABC (4 exercises) $\mathrm{x}(4 \mathrm{x} 20 \mathrm{~m})$, jump rope (4x1min:20s slow +20 s medium +20 s fast $)$

S2 (SPEED2): $(6 \times 10 \mathrm{~m})+(4 \times 20 \mathrm{~m})+(2 \times 30 \mathrm{~m})$

Weight training

W1 (Hipertropy1):[(4x10)x70\%] x (8 exercises)

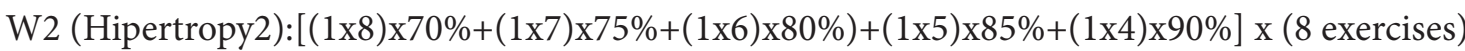

W4 (Maximal Strength):[4x(4x90\%)] x (8

exercises)

8 exercises: half squat, bench press, leg press, shoulder press, leg extension, leg curl, lat pull down, calf raise

W3 (Circuit Training):[2x(12x12x50\%) [8 + 4 exercises (sit up+back extension+leg abduction+leg adduction)] 


\section{Sprint Tests}

The handball players performed sprints $(10 \mathrm{~m}$, $20 \mathrm{~m}, 30 \mathrm{~m}$ ) on an indoor synthetic track. Each sprint was recorded by customized Precision Timing System (PTS) (MP501, Tümer Electronic Ltd, Turkey). Photocells of PTS were adjusted to trochanter height to standardize the cutting point of infrared light. The players commenced the sprint when they are ready on a standing start $1 \mathrm{~m}$ behind the first photocell. They performed 2 maximal sprints for each sprint distance on standing start with 2-3 min recovery following 15 min warmup including self-paced running, calisthenics and flexibility exercises. The better of the two trials for each test was retained for statistical analysis.

\section{Jump Tests}

Customized Precision Timing System (PTS) (Tümer Electronic Ltd, Turkey) was used to measure the time data needed to calculate the jump height and power in a vertical jump. The system included 2-channel of data acquisition, an electronic receiver, and a switching mat. Time data [flight time (FT) for SJ and CMJ] of SJ and CMJ sampled at $1000 \mathrm{~Hz}$ was recorded using of ESC 2XXX Series Data Acquisition Software of PTS. Formula-1 of Bosco et al. (Bosco, Luhtanen, \& Komi,1983) were used to obtain all jump height.

$$
\mathrm{H}=\mathrm{g} \cdot \mathrm{t}_{\mathrm{f}}^{2} \cdot 8^{-1} \cdot 100
$$

$\mathrm{H}=$ jump height $(\mathrm{cm}) ; \mathrm{g}=$ gravitational acceleration $\left(9.80665 \mathrm{~m} \cdot \mathrm{s}^{-2}\right) ; \mathrm{t}_{\mathrm{f}}=$ flight time $(\mathrm{s})$.

Each player had a 15-min warm-up including self-paced running, calisthenics and flexibility exercises before the tests. When performing SJ, the subjects flexed the knees until they felt a comfortable starting position, semi-squatting position, normally occurred at a knee angle of about $85^{\circ}$ (Bosco, \& Komi,1979) without a preliminary downward movement. CMJ was performed maximum jump with hands kept on the hips, started from an upright standing position following a preliminary downward movement by flexing the knee approximately to the same knee angle as the starting position in SJ. Elastic power $\left(\mathrm{CMJ}-\mathrm{SJ}_{\mathrm{dif}}\right)$ calculated from the difference between SJ and CMJ.

\section{Anaerobic Power and Capacity Test}

Anaerobic power and capacity (AP and AC) were tested with Wingate test (Monark Exercise $\mathrm{AB}$, Sweden), for $30 \mathrm{~s}$, at an "all out" pace. Each player warmed-up for a $5 \mathrm{~min}$ period (at 60-70 $\mathrm{rpm}$ ) after the ergometer was calibrated and seated height was adjusted for each player's leg length. The players pedaled up to their maximum rpm level at least 3 times during the 5 min period. A 5 -min recovery was followed after the warm-up and the appropriate amount of weight (between $1 \mathrm{~kg}$ and $100 \mathrm{gr})$ was placed on the weight carriage. With all resistance of the flywheel, the players were instructed to begin pedaling until they reached their maximum rpm within $4 \mathrm{~s}$. At this point, immediately the predetermined fixed resistance ( 75 gr per $\mathrm{kg}$ of body weight) was released to the flywheel and remained there till the end of the test (Inbar, BarOr, \& Skinner, 1996). Players were motivated in all test period. AP was the highest power output in $5 \mathrm{~s}$ interval of the test. AC was the mean power output in $30 \mathrm{~s}$ test. Relative values (W. $\mathrm{kg}^{-1}$ ) of AP and AC were used for statistical analysis.

\section{Aerobic Endurance Tests}

Aerobic endurance was determined by an incremental running test on a treadmill $(\mathrm{h} / \mathrm{p} / \mathrm{cosmos} /$ Gaitway, Germany). Players started running at 8 $\mathrm{km} \cdot \mathrm{h}^{-1}$ and took $30 \mathrm{~s}$ rest after $3 \mathrm{~min}$ running as stated by Midgley et al (Midgley, McNaughton, \& Caroll, 2007). Each of the following running load was $3 \mathrm{~min}$ followed by $30 \mathrm{~s}$ rest and the velocity increases was $1 \mathrm{~km} \cdot \mathrm{h}^{-1}$ up to fatigue. Blood samples were taken from ear lops during $30 \mathrm{~s}$ rest and were measured with electro enzymatic methods without any process in lactic acid analyzer (YSI 1500, Yellow Springs Instrument, USA). HR was recorded with a device (Polar s810i, Finland). $\mathrm{VO}_{2}$ for each breath was sampled with a mobile ergo-spirometer $\left(\mathrm{K}^{4} \mathrm{~b}^{2}\right.$, Italy). $\mathrm{HR}$ and $\mathrm{VO}_{2}$ in last 1 min of each running velocity were calculated. The third degree polynomial fit was used to estimate mean RV, HR, $\mathrm{VO}_{2}$ of induvidual FBLLs on these graphs (Jansen, 2001). It is evaluated as $\mathrm{VO}_{2} \max$ criteria as stated by Smith et al (Smith, McNaughton, \& Marshall, 1999). 


\section{Laboratory Conditions}

Laboratory conditions were measured with an anemometer $\left(0.1 \pm{ }^{\circ} \mathrm{C}, 0.1 \% \pm\right.$, Traceable, Control Company, USA) before each progressively increasing running test. Laboratory temperature and humidity were $24.0-25.5^{\circ} \mathrm{C}$ and $39.9-43.2 \%$.

\section{Statistical Analysis}

SPSS 20 software (SPSS Inc., Chicago, IL, USA) was used to analyze the data. Data are presented as mean, standard deviation (mean \pm SD). Normality of the distribution with Kolmogorov Smirnov test and homogeneity of variance with Levene test were calculated. Pre- and post-training differences of physiological performance characteristics were analyzed using by Paired samples t-test for the groups. Cohen's d effect size (ES) was used to compare the performance characteristics between ETG and NTG. ES magnitudes were classified according to the scale $(\geq 0.2=$ small; $0.2<\mathrm{ES}<0.8=$ moderate; $\leq 0.8=$ large) described by Cohen (1998). Probability level for statistical significance was set at $\mathrm{p} \leq 0.05$.

\section{RESULTS}

Pre- and post-training mean \pm SD and differences of female handball players in the 6-week pre-season plyometric training for sprints, jumps, anaerobic power-capacity, and aerobic running parameters at FBLLs were given in Table 2. All data were normally distributed and no violation of homogeneity of variance was found. ETG and NTG had no significant differences in the pre-training tests for any variable. 
Kale M., Effects of 6-week pre-season plyometric..., PHYSICAL CULTURE 2016; 70 (2): 145-154

Table 2. Effects of plyometric training on performance characteristics in female handball players

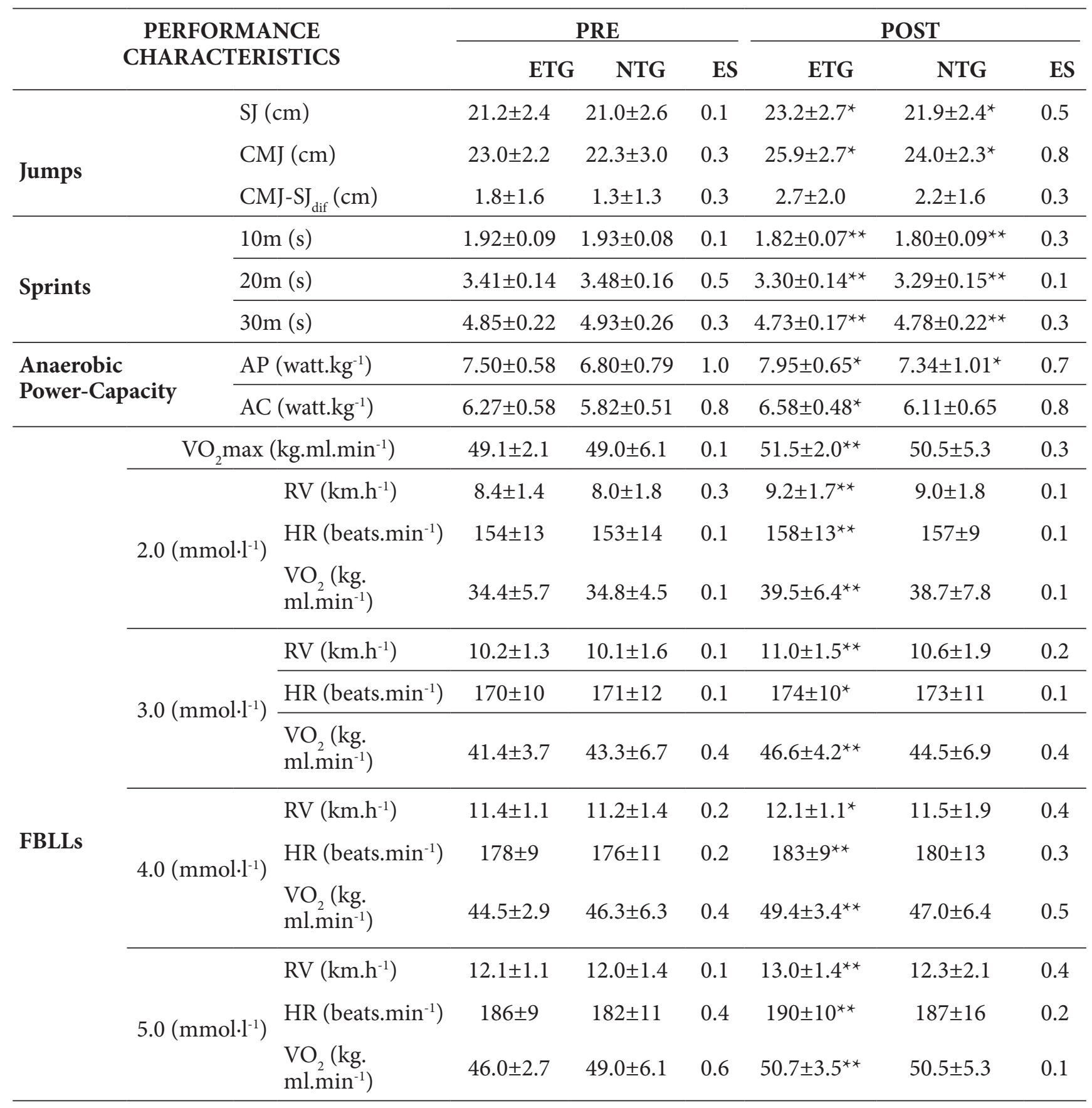

Note: Subject characteristics are given as Means \pm SD. ES $=$ effect size. FBLLs $=$ fixed blood lactate levels. Significant difference from pre-training values, ${ }^{*} \mathrm{p}<0.05,{ }^{*} \mathrm{p}<0.01$. 
Both groups had significant pre- and post-training differences in SS and CMJ $(\mathrm{p}<0.05)$. There were small and moderate ES differences in SS $(\mathrm{ES}=0.1)$, $\mathrm{CMJ}$, and CMJ-SJ dif $(\mathrm{ES}=0.3$, and $=0.3)$ between ETG and NTG in the pre-training. Moderate and large ES differences in the post-training between ETG and NTG were observed in SJ and CMJ-SJ dif $_{\text {(ES }}$ (E) $=0.5$ and $=0.3)$, and CMJ $(E S=0.8)$. Both groups had significant pre- and post-training differences in AP $(p<0.05)$. The ETG had only significant difference between pre and post-training in $\mathrm{AC}(\mathrm{p}<0.05)$. AP and AC had large ES differences in the pre-training (ES = 1.0 and $=0.8$ ), and moderate and large ES differences in post-training $(\mathrm{ES}=0.8$ and $=0.8)$ between $\mathrm{ETG}$ and NTG. There were significant decrease in sprints including $10 \mathrm{~m}, 20 \mathrm{~m}$, and $30 \mathrm{~m}(\mathrm{p}<0.01)$ from pre- to post-training in the both groups. Small ES differences in $10 \mathrm{~m}(\mathrm{ES}=0.1)$ and moderate $\mathrm{ES}$ differences in 20 $\mathrm{m}$ and $30 \mathrm{~m}(\mathrm{ES}=0.5$, and $=0.3)$ were present between ETG and NTG in the pre-training. There were moderate ES differences in $10 \mathrm{~m}$ and $30 \mathrm{~m}(\mathrm{ES}=0.3)$, and small ES differences in $20 \mathrm{~m}(\mathrm{ES}=0.1)$ between ETG and NTG in the post-training. ETG had significant pre- and post-training differences in the all-aerobic running parameters at each FBLL ( $p$ between $<0.01$ and $<0.05)$. ETG had also a significant change from pre- to post-training in $\mathrm{VO}_{2} \max (\mathrm{p}<0.01)$. There were no statistically significant changes in any aerobic running parameters at all FBLLs from pre- to post-training in NTG. There were small and moderate pre- and post-training ES differences in aerobic running parameters $(0.1 \leq \mathrm{ES} \leq 0.6)$, between ETG and NTG.

\section{DISCUSSION}

This study was aimed at examining the effects of the 6-week pre-season plyometric training on performance characteristics in female handball players.

There were significant pre- and post-training differences in ETG and NTG for SJ and CMJ in this study. Both groups increased SJ and CMJ after training. Nagano et al (Nagano, Komura, \& Fukashiro, 2007) have stated that maximum strength development with weight training, focusing on muscles around knee joint, and doing combined jumping workouts and teaching how to athlete uses these strengthened muscles improve athletes' jump performance. In the present study, it was shown that handball players were stressed with this type of training in the pre-season.
Gehri et al (Gehri, Ricard, Kleiner, \& Kirkendall, 1998) found that jumping ability developed with CMJ training that provided contractile component rather than elastic component due to higher positive energy production. Because the foot heel does not touch the floor immediately after landing on the floor, an athlete should produce an optimum jump performance related to short take off time. Markovic (2007) has stated that plyometric training improved SJ 4.7\%. When compared to Markovich (2007)'s study, the present study results have different outcomes. The pre-season training could be the reason for these differences because of individual training effects. Progressive intensive jump or sprint training can develop musculo-tendon complex elasticity and supportive structure of body via ability of energy storage (Elliott, Wagner, \& Chiu, 2007). Because of connective tissue adaptation and elasticity increase in this high force development, muscles specialized in sports are trained with exercises improving stretch shortening cycle. Plyometric training is an exercise method that uses stretch shortening cycle and jumping movement. Malisoux et al (Malisoux, Francaux, Nielens, \& Theisen, 2006) found $12 \%$ increases in muscle strength and $13 \%$ in vertical jump height after 8 weeks of training including plyometric jumps that effective for stretch shortening cycle exercise performance. Bosco and Komi (1979) stated that plyometric training was a loading consisting of concentric contractions after eccentric loading and thus they bring about stretch reflex, muscle elasticity, neuromuscular adaptation of the Golgi tendon organ (GTO). Stretch reflex is started at eccentric phase and thus it can help to recruit much more motor unit at concentric phase. Elastic power is stored in serial and parallel components of muscle connective tissue. When the power is transferred rapidly in concentric phase, additional force has occurred. The GTO has a protective function against load including extra tension in the muscle however, Hutton, \& Atwater, (1992) have stated that plyometric training caused loss of sensation in the GTO and had a potential for overcoming of more tension for elastic elements of muscle.

Sprint running is an important neuromuscular performance characteristic for success in elite female handball (Wagner et al, 2014; Granados et al, 2007). Relationships among running velocity, strength and muscular power of the knee extensor muscles have been found in elite female handball players, suggesting a possible transfer from the gain in leg muscle 
power into enhanced sprint performance (Jensen et al, 1998). Sprinting is involved multiple joints and segments that are delicately coordinated during each stance phase and requires different inter- and intra-muscular coordination. Young, McDowell, \& Scarlett (2001) found a significant increase in $30 \mathrm{~m}$ sprint performance after six-week sprint training in experienced team sport athletes. Chelly et al (Chelly, Hermassi, Aouadi, \& Shephard, 2014) stated that 8 -week in-season plyometric training significantly changed $0-5 \mathrm{~m}$ and $25-30 \mathrm{~m}$ sprint velocities. The studies are supported by the present study that there are significant pre- and post-training differences in $10 \mathrm{~m}$, $20 \mathrm{~m}$, and $30 \mathrm{~m}$ sprints $(\mathrm{p}<0.01)$. Therefore, it should be stated that a 6-week pre-season plyometric training for sprint running is an effective training method for handball players. The key points that handball players have an acceleration and chance direction in a short distance.

ETH and NTG had significant pre- and post-training differences in AP $(\mathrm{p}<0.05)$ but ETH only had a significant difference in $A C(p<0.05)$. No literature has been related to the effects of plyometric training on AP and AC in women handball players, which allows making a comparison. However, the result of present study showed that a 6-week plyometric training in pre-season helps to increase in AC.

There were significantly differences in ETG between pre- and post-training related to aerobic endurance parameters including $\mathrm{RV}, \mathrm{HR}$, and $\mathrm{VO}_{2}$ at all FBLLs in addition to $\mathrm{VO}_{2}$ max. This differences especially $\mathrm{VO}_{2}$ explained that the training effects occurred. Jensen et al (1997) found that $\mathrm{VO}_{2}$ max values of Norwegian women handball players in pre-training had $51.3 \pm 2.3 \mathrm{ml} . \mathrm{kg} . \mathrm{min}^{-1}$ and post-training 53.8 $\pm 2.7 \mathrm{ml} . \mathrm{kg} \cdot \mathrm{min}^{-1}$ but the present study has showed that $\mathrm{VO}_{2}$ max values of Turkish women handball players in pre-training was $49.0-49.1 \mathrm{ml} . \mathrm{kg} . \mathrm{min}^{-1}$ and in post-training was $50.5-51.5 \mathrm{ml} . \mathrm{kg} . \mathrm{min}^{-1}$. Although $\mathrm{VO}_{2}$ max values in Jensen et al (1997) have been high-

\section{REFERENCES}

1. Ache-Dias, J., Dellagrana, R.A., Teixeira, A.S., Dal Pupo, J., \& Moro, A.R. (2016). Effect of jumping interval training on neuromuscular and physiological parameters: a randomized controlled study. Applied Physiology, Nutrition and Metabolism, 41(1), 20-25. er than the present study, there are similar increases in these two studies as training effects. As results of these two studies, it can be claimed that a 6-week plyometric training during pre-season has positive contributions to aerobic capacity of women handball players. The athletes, at a higher $\mathrm{VO}_{2}$ max level, show higher accomplishment to resynthesize of phosphocreatine after high intensity intermittent workouts (Tomlin, \& Wenger, 2001). Besides this, plyometric training enhances strength and power development. The application of carefully programmed plyometric training can have potentially positive effects of aerobic endurance training varieties in $\mathrm{RV}, \mathrm{HR}$, or $\mathrm{VO}_{2}$ at FBLLs reflecting regeneration, extensive and intensive tempo, extensive and intensive interval. Jumping interval training included in traditional endurance training induces moderate to large effects on neuromuscular and physiological parameters (Ache-Dias, Dellagrana, Teixeira, Dal Pupo, \& Moro, 2016) and can be fundamental to enhance female handball players' performance. Training volume and training intensity can also be oriented.

\section{CONCLUSION}

Pre-season training results in significant increases in sprints, squat and countermovement jumps, $\mathrm{VO}_{2}$ max, RV, HR, and $\mathrm{VO}_{2}$ at FBLLs in female handball players. Such increases are likely to be considered advantages because these bio-motor characteristics give the athletes forceful muscle contractions as well as necessary endurance for some handball game actions, such as sprinting, throwing, blocking, jumping, pushing and shuttle-run. In conclusion, it was found that a 6-week plyometric training is an important parameter in addition to physical fitness, technical and tactical training for the female handball players who get prepared for the woman handball Super League which affects pre-season performance characteristics.

2. Adams, K, O'Shea, J.P., O'Shea, K.L., \& Climstein, M. (1992). The effects of six weeks of squat, plyometrics, and squat plyometric training on power production. Journal of Applied Sport Science Research, 6, 36-41. 
3. Bosco, C., \& Komi, P.V. (1979). Potentiation of the mechanical artifact of the human skeletal muscle through prestretching. Acta Physiologics Scandinavica, 106, 467-472.

4. Bosco, C., Luhtanen, P., \& Komi, P.V. (1983). A simple method for measurement of mechanical power in jumping. European Journal of Applied Physiology, 50, 273-282.

5. Cavala, M., \& Katic, R. (2010). Morphological, motor and situation- motor characteristics of elite female handball players according to playing performance and position. Collegium Antropolgicum, 34(4), 1355-1361.

6. Chelly, M.S., Hermassi, S., Aouadi, R., \& Shephard, R.J. (2014). Effects of 8-week in-season plyometric training on upper and lower limb performance of elite adolescent handball players. Journal of Strength \& Conditioning Research, 28(5), 1401-1410.

7. Cohen, J. (1988). Statistical power analysis for the behavioral sciences. 2nd ed. Hillsdale, New Jersey: Lawrence Earlbaum Associates.

8. Elliott, M.C.C.W., Wagner, P.P., \& Chiu, L. (2007). Power athletes and distance training: physiologi$\mathrm{cal}$ and biomechanical rationale for change. Sports Medicine, 37(1), 47-57.

9. Gehri, D.J., Ricard, M.D., Kleiner, D.M., \& Kirkendall, D.T. (1998). A comparison of plyometric training techniques for improving vertical jump ability and energy production. Journal of Strength \& Conditioning Research, 12(2), 85-89.

10. Gorostiaga, E.M., Granados, C., Ibanez, J., Gonzalez-Badillo, J.J., \& Izquierdo, M. (2006). Effects of an entire season on physical fitness changes in elite male handball players. Medicine \& Science in Sports \& Exercise, 38(2), 357-366.

11. Granados, C., Izquierdo, M., Ibanez, J., Bonnabau, H., \& Gorostiaga, E.M. (2007). Differences in physical fitness and throwing velocity among elite and amateur female handball players. International Journal of Sports Medicine, 28(10), 860-867.

12. Hutton, R.S., \& Atwater, S.W. (1992). Acute and chronic adaptations of muscle proprioceptors in response to increased use. Sports Medicine, 14(6), 406-421.
13. Inbar, O., Bar-Or, O., \& Skinner, J.S. (1996). The Wingate anaerobic test. Champaign, IL: Human Kinetics.

14. Janssen, P.G. (2001). Lactate threshold training. Champaign, IL: Human Kinetics.

15. Jensen, J., Jacobsen, S.T., Hetland, S., \& Tveit, P. (1997). Effect of combined endurance, strength and sprint training on maximal oxygen uptake, isometric strength and sprint performance in female elite handball players during a season. International Journal of Sports Medicine, 18, 354-358.

16. Karcher, C., \& Bucheit, M. (2014). On-court demands of elite handball, with special reference to playing positions. Sports Medicine, 44(6), 797814.

17. Malisoux, L., Francaux, M., Nielens, H., \& Theisen, D. (2006). Stretch-shortening cycle exercises: an effective training paradigm to enhance power output of human single muscle fibers. Journal of Applied Physiology, 100(3), 771-779.

18. Markovic, G. (2007). Does plyometric training improve vertical jump height? A meta-analytical review. British Journal of Sports Medicine, 41(6), 349-355.

19. Massuca, LM, Fragoso, I., \& Teles, J. (2014). Attributes of top elite team-handball players. Journal of Strength \& Conditioning Research, 28(1), 178-186.

20. Midgley, A.W., McNaughton, L.R., \& Caroll, S. (2007). Time at VO2max during intermittent treadmill running: test protocol dependent or methodological artifact? International Journal of Sports Medicine, 28(11), 934-939.

21. Nagano, A., Komura, T., \& Fukashiro, S. (2007). Optimal coordination of maximal-effort horizontal and vertical jump motions - a computer simulation study. BioMedical Engeneering OnLine, 6(20), 1-9.

22. Ronglan, L.T., Raastad, T., \& Børgese, A. (2006). Neuromuscular fatigue and recovery in elite female handball players. Scandinavian Journal of Medicine \& Science in Sport, 16, 267-273.

23. Smith, T.P., McNaughton, L.R., \& Marshall, K.J. (1999). Effects of 4-week training using Vmax/ Tmax on VO2max and performance in athletes. Medicine \& Science in Sports \& Exercise, 31(6), 892-896. 
24. Tomlin, D.L. \& Wenger, H.A. (2001). The relationship between aerobic fitness and recovery from high intensity intermittent exercise. Sport Medicine, 31(1), 1-11.

25. Vicente-Rodrigueza, G., Doradoa, C., PerezGomeza, J., Gonzalez-Henriquezbi, J.J., \& Calbet, J.A.L. (2004). Enhanced bone mass and physical fitness in young female handball players. Bone, $35,1208-1215$.
26. Wagner, H., Finkenzeller, T., Wurth, S., \& von Duvillard, S.P. (2014). Individual and team performance in team-handball: a review. Journal of Sports Science \& Medicine, 13(4), 808-816.

27. Young, W.B., McDowell, M.H., \& Scarlett, B.J. (2001). Specificity of sprint and agility training methods. Journal of Strength \& Conditioning Research. 15, 315-319.

\title{
EINFLUSS EINES 6-WÖCHIGEN PLYOMETRISCHEN TRAININGS IN DER VORSAISON AUF PERFORMANCECHARAKTERISTIKEN VON HANDBALLSPIELERINNEN
}

\begin{abstract}
Zusammenfassung:
Ziel dieser Untersuchung war es, die Einflüsse eines 6-wöchigen plyometrischen Trainings in der Vorsaison auf die Charakteristiken der Performance von Handballspielerinnen festzustellen. An der Untersuchung nahmen auf freiwilliger Basis 19 Handballspielerinnen teil. Sie wurden in 2 Gruppen geteilt [(Experimentalgruppe (ETG) $(\mathrm{N}=10)$ und Kontrollgruppe (NTG) $(\mathrm{N}=9)$ ]. Beide Gruppen trainierten regelmäßig in der Vorsaison während eines Zeitraums von 6 Wochen. Die Experimentalgruppe (ETG) hatte auch ein plyometrisches Training. Sprints (10 m, $20 \mathrm{~m}$ und $30 \mathrm{~m})$, Sprung aus der Hocke (SJ), Absprung mit beiden Beinen (CMJ), anaerobe Ausdauer und Kapazität (AP und AC) sowie aerobe Variablen bei fixen Schwellen von Laktat im Blut (FBLL) [Laufgeschwindigkeit (RV), Puls (HR) und Sauerstoffverbrauch (VO2)] wurden vor und nach dem Training gemessen und verglichen. Die Ergebnisse zeigten bedeutende Unterschiede im SJ und CMJ ( $<<0,05)$, sowie bei allen Sprintarten $(\mathrm{p}<0,01)$, bei AP und AC $(\mathrm{p}<0.05), \operatorname{VO} 2 \mathrm{max}(\mathrm{p}<$ 0.01 ), RV, HR und VO2 bei jedem der FBLL $(\mathrm{p}<0.01)$ vor und nach dem Training der Experimentalgruppe (ETG). Die Egebnisse vor und nach dem Training verweisen ebenfalls auf bedeutende Unterschiede bei SJ und CMJ $(p<0.05)$, bei allen Sprintarten ( $\mathrm{p}$ 0.01) und AP ( $\mathrm{p}<0.05)$ in der Kontrollgruppe (NTG). Die Ergebnisse führen zur Schlussfolgerung, dass ein 6-wöchiges plyometrisches Training neben körperlicher Bereitschaft, technischem und taktischem Training einen wichtigen Parameter für die Charakteristiken der Performance in der Vorsaison bei Handballspielerinnen darstellen, die sich für die Superliga im Frauenhandball vorbereiten.
\end{abstract}

Schlüsselwörter: PLYOMETRISCHES TRAINING / SPRUNG / SPRINT / FIXE SCHWELLE VON LAKTAT IM BLUT

Received: 15.05.2016.

Accepted: 02.11.2016.

() 2016 The Author. Published by Physical Culture (www.fizickakultura.com). This article is an open access article distributed under the terms and conditions of the Creative Commons Attribution license (http://creativecommons. org/licenses/by/3.0/rs/).

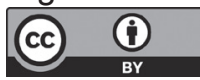




\title{
УТИЦАЈИ ШЕСТОНЕДЕЉНОГ ПЛИОМЕТРИЈСКОГ ТРЕНИНГА У ПРЕДСЕЗОНИ НА КАРАКТЕРИСТИКЕ ПЕРФОРМАНСИ РУКОМЕТАШИЦА
}

\author{
Мехмет Кале \\ Анадолски универзитет, Факултет спортских наука, Департман спортског тренинга Ескизехир, Турска
}

\begin{abstract}
Сажетак
Циљ овог истраживања је био да се испитају утицаји шестонедељног плиометријског тренинга у предсезони на карактеристике перформанси рукометашица. У истраживању је добровољно учествовало деветнаест рукометашица. Подељене су у 2 групе [експериментална група (ЕТГ) $(\mathrm{N}=10)$ и контролна група $(\mathrm{HT \Gamma})(\mathrm{N}=$ 9)]. Обе групе су редовно тренирале у предсезони током 6 недеља. Експериментална група је такође имала и плиометријски тренинг. Спринтеви (10 м, 20 м и 30 м), чучањ скок (SJ), суножни скок (CMJ), анаеробна снага и капацитет (AP i AC), као и аеробне варијабле при фиксним нивоима лактата у крви (FBLL) [брзина трчања (RV), пулс (HR) и потрошња кисеоника $\left.\left(\mathrm{VO}_{2}\right)\right]$ упоређивани су пре и после тренинга. Резултати су показали да постоје значајне разлике у SJ і CMJ (p<0.05), свим спринтевима (p<0.01), AP и AC (p<0.05), VO $\max (\mathrm{p}<0.01), \mathrm{RV}, \mathrm{HR}$ и $\mathrm{VO}_{2}$ при сваком од FBLL $(\mathrm{p}<0.01)$ пре и после тренинга експерименталне групе. Резултати пре и после тренинга су такође значајно различити у SJ и СMJ $(\mathrm{p}<0.05)$, свим спринтевима $(\mathrm{p}<0.01)$ и AP $(\mathrm{p}<0.05)$ у нормалној групи. Закључује се да је шестонедељни плиометријски тренинг, поред физичке спремности, техничког и тактичког тренинга, важан параметар који утиче на карактеристике перформанси у предсезони код рукометашица које се припремају за женску рукометну супер лигу.
\end{abstract}

Кључне речи: ПЛИОМЕТРИЈСКИ ТРЕНИНГ / СКОК / СПРИНТ / ФИКСНИ НИВО ЛАКТАТА У КРВИ

\section{УВОД}

Рукомет је једна од спортских активности која укључује велики број физичких контаката међу играчима и различите покрете доњих екстремитета попут стартова, заустављања, скокова, доскока, брзих промена правца кретања, поновљених убрзања и спринтева, што изазива висок ниво механичког стреса на доње екстремитете услед јаких сила реакције тла и различитих покрета горњих екстремитета попут бацања лопте, доскока при паду и блокирања лопте (Vicente-Rodrigueza, Doradoa, Perez-Gomeza, Gonzalez-Henriquezbi, \& Calbet, 2004; Ronglan, Raastad, \& Børgese, 2006; Cavala, \& Katic, 2010; Massuca, Fragoso, \& Teles, 2014; Karcher, \& Bucheit, 2014; Wagner, Finkenzeller, Wurth, \& von Duvillard, 2014). Ови покрети излажу различите мишиће великом напору и стварају замор, што подразумева одређени временски период опоравка како би се повратио уобичајени ниво перформанси (Ronglan et al.,, 2006). Рукометаши који су изложени великом оптерећењу током тренинга треба да прикажу висок ниво силе, мишићне снаге, спринта и издржљивости у трчању (Granados, Izquierdo, Ibanez, Bonnabau, \& Gorostiaga, 2007). Показало се да се перформансе у рукомету могу побољшати специфичним условљавањем рукомета сложеним тренингом отпорности, спринта и издржљивости, поред техничког тренинга (Jensen, Jacobsen, Hetland, \& Tveit, 1997). Сложени тренинг је неопходан за брзу, експлозивну и снажну способност контракције мишића рукометаша. Прилагођавања на овај сложени тренинг представљају тоталне промене настале редовним вежбањем. Међутим, о оптималном начину и релативним утицајима које специфични тренинг има на перформансе се мало зна. Горостиага и сарадници (Gorostiaga, Granados, 
Ibanez, Gonzalez-Badillo, \& Izquierdo, 2006) су открили значајне везе између излазне мишићне снаге горњих и доњих телесних екстремитета која је повезана са тренингом снаге и тренинга издржљивости високог интезитета током читаве тренажне сезоне код врхунских рукометаша. Испитивање утицаја тренинга би могло да буде од великог значаја за оптималну израду физичких и спортом одређених програма условљавања ради побољшања перформанси у рукомету (Jensen et al, 1997). Ако су физичко условљавање, техничке и тактичке вежбе у рукомету довољно добри да обезбеде адекватне стимулансе, нарочито за побољшање мишићне снаге, физичке перформансе рукометашица се могу унапредити. Одређују се физиолошке и био-моторичке карактеристике, а тренажни програми се планирају у погледу тих карактеристика у оквиру тренажних програма у којима се користе испитивања спортске перформансе у лабораторијским условима и условима на терену.

Могуће је утврдити физиолошке промене проузроковане плиометријским тренингом, како би се идентификовало физичко стање спортиста након плиометријског тренинга, као и да би се одредило стање перформанси спортиста који имају потенцијал за нову тренажну фазу. Процена спринта, скока, анаеробне снаге-капацитета и мишићне снаге открива важне појединости о тренажном статусу рукометашица. Са овог становишта, није било студија које су испитивале параметре условљавања у рукомету праћене током тренажних фаза, као ни квантитативне процене тренинга и такмичења врхунских рукометашица. Стога, циљ овог истраживања је био да се испитају утицаји шестонедељног плиометријског тренинга у предсезони на карактеристике перформанси рукометашица.

\section{МЕТОД}

\section{Узорак испитаника}

У истраживању је добровољно учествовало 19 рукометашица из једног тима Супер Лиге. Све испитанице су имале редован тренинг снаге/силе најмање три пута недељно током периода од минимум 4 године. Биле су подељене у групе ЕТГ (старост: $20.4 \pm 3.0$ године, висина: $170.7 \pm 5.5$ цм, тежина: $65.8 \pm 8.3$ кг) и НТГ (старост: $19.4 \pm 3.3$ године, висина: $172.6 \pm 3.9 ц м$, тежина: $66.6 \pm 9.1$ кг). Сагласност за учествовање у истраживању у писаном облику добијена је од сваке испитанице у складу са етичким стандардима Хелсиншке декларације. Истраживање је одобрио етички комитет Универзитета Османгази.

\section{Поступци}

Свака играчица је тестирана на почетку и крају предсезоне пре и после тренинга, а након посета лабораторији и посета на терену у трајању од 45-60 минута за сваки тест у одређено доба дана (16:00-17:00) у четири наврата како би се употпунило упознавање са циљем испитивања. Играчице су учествовале у тестирањима која су обухватала спринтеве (10 м, 20 м, 30 м), вертикалне скокове (SJ, CMJ), анаеробну снагу-капацитет и аеробну издржљивост $\left[\mathrm{RV}, \mathrm{HR}, \mathrm{VO}_{2}\right.$ при FBLL од $2.0 \mathrm{mM} . \mathrm{L}^{-1}$ (регенерација) (AE1), $3.0 \mathrm{mM} . \mathrm{L}^{-1}$ (интезивни темпо) (AE2), 4.0 mM.L. ${ }^{-1}$ (екстезивни интервал) (AE3), $5.0 \mathrm{mM} . \mathrm{L}^{-1}$ (интензивни интервал) (AE4)] насумичним редоследом.

\section{Тренажни период}

Oঠe групе су прошле шестонедељни тренинг физичке спремности, технички тренинг (ТЕ) и тактички тренинг (ТА), као и тренажну игру (ТГ) у предсезони (Табела 1). Свака недеља је обухватала 5 дана тренинга и 2 дана одмора средом и недељом. Сваки тренажни дан је обухватао двочасовни јутарњи тренинг и двочасовни вечерњи тренинг. Сваки тренинг је започињао загревањем од 15 минута укључујући трчање прилагођеним темпом, вежбе обликовања и вежбе истезања, а завршавао се хлађењем од 10 минута укључујући трчање прилагођеним темпом и вежбе истезања. ЕТГ група је имала додатни плиометријски тренинг [4 вежठе (скокови са препонама, бочни вишеструки скокови за плантарне флексоре и екстензоре ногу и фронтални вишеструки скокови) од 3 серије по 12 понављања]. Одмор од 30-40 с је био дозвољен између вежби, као и пауза од 3 минута између серија. Вежбе су биле укључене првог и четвртог дана сваке тренажне недеље како би се омогућио довољан опоравак између тренинга по препоруци истраживача Адамса и сарадника (Adams, O'Shea, O'Shea, \& Climstein 1992). 
Табела 1. Компоненте тренинга за 6 недеља у предсезони

\begin{tabular}{|c|c|c|c|c|c|c|c|c|}
\hline \multirow[t]{2}{*}{ Недеља } & \multirow[t]{2}{*}{ Сесисја } & \multicolumn{7}{|c|}{ Дан } \\
\hline & & 1 & 2 & 3 & 4 & 5 & 6 & 7 \\
\hline \multirow[t]{2}{*}{1} & $\mathrm{AM}$ & $\mathrm{S} 1, \mathrm{~W} 1, \mathrm{~A} 1_{10}$ & $\mathrm{~S} 2, \mathrm{~W} 3, \mathrm{~A} 1_{10}$ & $\mathrm{R}$ & $\mathrm{S} 1, \mathrm{~W} 4, \mathrm{~A} 1_{10}$ & $\mathrm{~S} 2, \mathrm{~W} 2, \mathrm{~A} 4_{1}, \mathrm{~A} 1_{10}$ & $\mathrm{R}$ & $\mathrm{R}$ \\
\hline & PM & $\mathrm{TE}_{60}, \mathrm{~A} 2_{15}$ & $\mathrm{TE}_{60}, \mathrm{~A} 3_{4}$ & $\mathrm{R}$ & $\mathrm{TE}_{60}, \mathrm{~A} 2_{20}$ & $\mathrm{TE}_{30}, \mathrm{~A} 1_{15}$ & TG & $\mathrm{R}$ \\
\hline \multirow[t]{2}{*}{2} & $\mathrm{AM}$ & $\mathrm{S} 1, \mathrm{~W} 1, \mathrm{~A} 1_{10}$ & $\mathrm{~S} 2, \mathrm{~W} 3, \mathrm{~A} 1_{10}$ & $\mathrm{R}$ & $\mathrm{S} 1, \mathrm{~W} 4, \mathrm{~A} 1_{10}$ & $\mathrm{~S} 2, \mathrm{~W} 2, \mathrm{~A} 4_{2}, \mathrm{~A}_{10}$ & $\mathrm{R}$ & $\mathrm{R}$ \\
\hline & $\mathrm{PM}$ & $\mathrm{TE}_{60}, \mathrm{~A} 2_{20}$ & $\mathrm{TE}_{60}, \mathrm{A3}_{5}$ & $\mathrm{R}$ & $\mathrm{TE}_{60}, \mathrm{~A}_{25}$ & $\mathrm{TE}_{30}, \mathrm{~A} 1_{15}$ & TG & $\mathrm{R}$ \\
\hline \multirow[t]{2}{*}{3} & $\mathrm{AM}$ & $\mathrm{S} 1, \mathrm{~W} 1, \mathrm{~A} 1_{10}$ & $\mathrm{~S} 2, \mathrm{~W} 3, \mathrm{~A} 1_{10}$ & $\mathrm{R}$ & $\mathrm{S} 1, \mathrm{~W} 4, \mathrm{~A} 1_{10}$ & $\mathrm{~S} 2, \mathrm{~W} 2, \mathrm{~A} 4_{3}, \mathrm{~A} 1_{15}$ & $\mathrm{R}$ & $\mathrm{R}$ \\
\hline & $\mathrm{PM}$ & $\mathrm{TE}_{60}, \mathrm{~A}_{25}$ & $\mathrm{TE}_{60}, \mathrm{~A}_{6}$ & $\mathrm{R}$ & $\mathrm{TE}_{60}, \mathrm{~A}_{30}$ & $\mathrm{TE}_{30}, \mathrm{~A}_{15}$ & TG & $\mathrm{R}$ \\
\hline \multirow[t]{2}{*}{4} & $\mathrm{AM}$ & $\mathrm{S} 1, \mathrm{~W} 1, \mathrm{~A} 1_{10}$ & $\mathrm{~S} 2, \mathrm{~W} 3, \mathrm{~A} 1_{10}$ & $\mathrm{R}$ & $\mathrm{S} 1, \mathrm{~W} 4, \mathrm{~A} 1_{10}$ & $\mathrm{~S} 2, \mathrm{~W} 2, \mathrm{~A} 4_{1}, \mathrm{Al}_{10}$ & $\mathrm{R}$ & $\mathrm{R}$ \\
\hline & $\mathrm{PM}$ & $\mathrm{TE}_{60}, \mathrm{~A}_{2}$ & $\mathrm{TE}_{60}, \mathrm{~A}_{4}$ & $\mathrm{R}$ & $\mathrm{TE}_{60}, \mathrm{~A} 2_{20}$ & $\mathrm{TE}_{30}, \mathrm{~A}_{15}$ & TG & $\mathrm{R}$ \\
\hline \multirow[t]{2}{*}{5} & $\mathrm{AM}$ & $\mathrm{S} 1, \mathrm{~W} 1, \mathrm{~A} 1_{10}$ & $\mathrm{~S} 2, \mathrm{~W} 3, \mathrm{~A} 1_{10}$ & $\mathrm{R}$ & $\mathrm{S} 1, \mathrm{~W} 4, \mathrm{~A} 1_{10}$ & $\mathrm{~S} 2, \mathrm{~W} 2, \mathrm{~A} 4_{2}, \mathrm{~A} 1_{10}$ & $\mathrm{R}$ & $\mathrm{R}$ \\
\hline & $\mathrm{PM}$ & $\mathrm{TE}_{60}, \mathrm{~A} 2_{20}$ & $\mathrm{TA}_{60}, \mathrm{~A} 3_{5}$ & $\mathrm{R}$ & $\mathrm{TE}_{60}, \mathrm{~A} 2_{25}$ & $\mathrm{TA}_{30}, \mathrm{~A} 1_{15}$ & TG & $\mathrm{R}$ \\
\hline \multirow[t]{2}{*}{6} & $\mathrm{AM}$ & $\mathrm{S} 1, \mathrm{~W} 1, \mathrm{~A} 1_{10}$ & $\mathrm{~S} 2, \mathrm{~W} 3, \mathrm{~A} 1_{10}$ & $\mathrm{R}$ & $\mathrm{S} 1, \mathrm{~W} 4, \mathrm{~A} 1_{10}$ & $\mathrm{~S} 2, \mathrm{~W} 2, \mathrm{~A} 4_{3}, \mathrm{~A} 1_{15}$ & $\mathrm{R}$ & $\mathrm{R}$ \\
\hline & $\mathrm{PM}$ & $\mathrm{TE}_{60}, \mathrm{~A} 2_{25}$ & $\mathrm{TA}_{60}, \mathrm{~A}_{6}$ & $\mathrm{R}$ & $\mathrm{TA}_{60}, \mathrm{~A} 2_{30}$ & $\mathrm{TA}_{30}, \mathrm{Al}_{15}$ & TG & $\mathrm{R}$ \\
\hline
\end{tabular}

Програм тренинга: серија х (серија х понављања)

Аеробни тренинг

$\mathrm{Al}_{10}: 10 \mathrm{~min}, \mathrm{~A} 1_{15}: 15 \mathrm{~min}$

$\mathrm{A} 2_{15}: 15 \mathrm{~min}, \mathrm{~A} 2_{20}: 20 \mathrm{~min}, \mathrm{~A} 2_{25}: 25 \mathrm{~min}, \mathrm{~A} 2_{30}: 30 \mathrm{~min}$

$\mathrm{A} 33_{4}: 2 \mathrm{x}(2 \times 4 \mathrm{~min}), \mathrm{A}_{5}: 2 \mathrm{x}(2 \times 5 \mathrm{~min}), \mathrm{A}_{6}: 2 \mathrm{x}(2 \times 6 \mathrm{~min})$

$\mathrm{A} 44_{1}: 2 \mathrm{x}(2 \mathrm{x} 1 \mathrm{~min}), \mathrm{A} 4_{2}: 2 \mathrm{x}(2 \mathrm{x} 2 \mathrm{~min}), \mathrm{A}_{3}: 2 \mathrm{x}(2 \times 3 \mathrm{~min})$

$\mathrm{TE}_{30}: 30 \mathrm{dk}, \mathrm{TE}_{60}: 60 \mathrm{dk}$

$\mathrm{TA}_{30}: 30 \mathrm{dk}, \mathrm{TA}_{60}: 60 \mathrm{dk}$

Тренинг брзине

S1 (SPEED1):спринт ABC (4 вежбе) $\mathrm{x}(4 \mathrm{x} 20 \mathrm{~m})$, вијсача (4x1min:20s споро $+20 \mathrm{~s}$ средње $+20 \mathrm{~s}$ брзо)

S2 (SPEED2): $(6 \times 10 \mathrm{~m})+(4 \times 20 \mathrm{~m})+(2 \times 30 \mathrm{~m})$

Тренинг снаге

W1 (Хипертрофија1):[(4x10)x70\%] x (8 вежби)

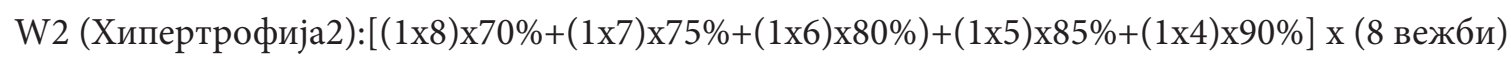

W4 (Максимална снага):[4x(4x90\%)] х (8 веж

би)

8 вежби: получучањ, „бенч прес“, лег прес, рамени потисак, опружање ногу, савијсање ногу, повлачење на доле, подизање на прсте

W3 (Кружни тренинг):[2x(12x12x50\%) [8 + 4 вежбе (склекови+исправљање леђа+одвођење ноге +привођење ноге)] 


\section{Спринт тестови}

Рукометашице су трчале спринтеве $(10 \mathrm{~m}$, $20 \mathrm{~m}, 30 \mathrm{~m})$ на синтетичкој стази у затвореном. Сваки спринт је забележен помоћу прилагођеног Система за прецизно мерење времена (ПТС) (MP501, Tümer Electronic д.o.o, Турска). Фотоћелије система ПТС су биле подешене на трохантеричну висину да би се стандардизовала тачка обраде инфрацрвеног светла. Играчице су започињале спринт када су биле спремне на старту у стојећем ставу, $1 \mathrm{~m}$ иза прве фотоћелије. Изводиле су 2 максимална спринта за сваку спринт дистанцу стартујући у стојећем ставу уз 2-3 минута опоравка после загревања од 15 минута које је укључивало трчање прилагођеним темпом, вежбе обликовања и вежбе истезања. За статистичку анализу узимао се бољи од два покушаја за сваки тест.

\section{Тестови скокова}

Прилагођени систем за прецизно мерење времена (PTS) (Tümer Electronic d.o.o, Turska) je коришћен како би се измерили временски подаци потребни да се израчуна висина скока и снага при вертикалном скоку. Систем је обухватао 2 канала прикупљања података, електронски пријемник и прекидач. Временски подаци [време лета (FT) за SJ и CMJ] за SJ и CMJ узорковани при $1000 \mathrm{~Hz}$ забележени су помоћу софтвера за прикупљање података серије ЕСЦ 2XXX система ПТС. Формула-1 коју су поставили Боско и сарадници (Bosco, Luhtanen, \& Komi, 1983) коришћена је да би се добиле све висине скокова.

$$
\mathrm{H}=\mathrm{g} \cdot \mathrm{t}_{\mathrm{f}}^{2} \cdot 8^{-1} \cdot 100
$$

$\mathrm{H}=$ висина скока $(\mathrm{cm}) ; \mathrm{g}=$ гравитационо убрзање $\left(9.80665 \mathrm{~m} \cdot \mathrm{s}^{-2}\right) ; \mathrm{t}_{\mathrm{f}}=$ време лета $(\mathrm{s})$.

Свака рукометашица је имала загревање од 15 минута које је укључивало трчање прилагођеним темпом, вежбе обликовања и вежбе истезања пре тестирања. При извођењу SJ, испитанице су савијале колена док се не би нашле у оптималној стартној позицији, получучећој позицији, која се обично јавља при углу колена од око 85 (Bosco, \& Komi,1979) без претходног кретања надоле. СМJ је извођен као максимал- ни скок са шакама на куковима, који започиње од усправног стојећег положаја након претходног покретања надоле савијањем колена до отприлике истог угла као и приликом стартне позиције у SJ. Еластична сила $\left(\mathrm{CMJ}-\mathrm{SJ}_{\mathrm{duf}}\right)$ се израчунавала као разлика између SJ и CMJ.

\section{Тест анаеробне снаге и капацитета}

Анаеробна снага и капацитет (AР и АC) су процењивани помоћу Вингејт теста (Monark стационирани бицикл, Шведска), у трајању од 30 c, при максималној брзини “до отказа”. Свака играчица се загревала 5 минута (при 60-70 обртаја/мин) након што је ергометар калибрисан и висина седишта подешена према дужини ногу за сваку играчицу. Рукометашице су окретале педале до свог максималног нивоа обртаја у минути најмање 3 пута током 5 минута. Петоминутни одмор је следио након загревања, а одговарајућа количина терета (између $1 \mathrm{~kg}$ и 100 g) је постављена на носач терета. Уз сав отпор замајца, играчицама је дато упутство да почну да окрећу педале док не постигну максимални број обртаја у минути у року од 4 с. У том тренутку, претходно одређени фиксни отпор (75 g по kg телесне тежине) је одмах ослобађан на замајцу и остајао је тамо до краја теста (Inbar, Bar-Or, \& Skinner, 1996). Играчице су биле мотивисане у свим периодима тестирања. АР је била највиша излазна снага у интервалу теста од 5s. AC је била средња излазна снага у интервалу теста од $30 \mathrm{~s}$. Релативне вредности (W. kg-1) анаеробне снаге и капацитета су коришћене за статистичку анализу.

\section{Тестови аеробне издржљивости}

Аеробна издржљивост је утврђена помоћу теста трчања на тредмил траци са постепеним повећањем оптерећења (h/p/cosmos/Gaitway, Немачка). Играчице су почињале да трче при $8 \mathrm{~km} \cdot \mathrm{h}^{-1}$ и имале одмор од $30 \mathrm{~s}$ након 3 минута трчања како су навели Мидглеј и cap. (Midgley, McNaughton, \& Caroll, 2007). Свако од наредних оптерећења трчања износило је 3 минута након чега је следио одмор од 30 с и повећање брзине је износило 1 км. $\mathrm{x}^{-1}$ до замора. Узорци крви су узимани из ушне ресице током паузе од 
30 с и мерени су електро ензимским методама без икакве обраде у анализатору млечне киселине (YSI 1500, Yellow Springs Instrument, САД). Пулс (HR) је измерен помоћу уређаја (Polar s810и, Финска). $\mathrm{BO}_{2}$ за сваки удах је узоркован помоћу мобилног ерго-спирометра (K4b², Италија). $\mathrm{HR}$ и $\mathrm{VO}_{2}$ су израчунавани у последњем минуту трчања при свакој брзини. Трећи степен полиномске функције је коришћен како би се процениле средње вредности RV, $\mathrm{HR}$ и $\mathrm{VO}_{2}$ појединачних FBLL нивоа на овим графицима (Jensen, 2001). Ово се сматра критеријумом за процену $\mathrm{BO}_{2}$ мах како су навели Смит и сарадници (Smith, McNaughton, \& Marshall 1999).

\section{Лабораторијски услови}

Лабораторијски услови су измерени помоћу анемометра $\left(0.1 \pm{ }^{\circ} \mathrm{C}, 0.1 \% \pm\right.$, следљиво, Control Company, САД) пре сваког теста прогресивно повећаваног трчања. Лабораторијска температура и влажност су износили 24.0-25.5 ${ }^{\circ} Ц$ и $39.9-43.2 \%$.

\section{Обрада података}

За анализу података коришћен је софтвер SPSS 20 (SPSS Inc., Чикаго, САД). Подаци су представљени као средња вредност, стандардна девијација (М土СД). Нормалност дистрибуције је израчуната Колмогоров Смирнов тестом, а хомогеност варијансе Левеновим тестом. Разлике у физиолошким карактеристикама перформансе пре и после тренинга анализиране су употребом упарених узорака т-теста за групе. Коенова д величина ефекта (ЕС) коришћена је како би се упоредиле карактеристике перформанси између ЕТГ и НТГ. ЕС величине су класификоване према скали ( $\geq 0.2=$ мала; $0.2<\mathrm{EC}$ $<0.8$ = умерена; $\leq 0.8=$ велика) како је описао Коен (Cohen, 1998). Ниво вероватноће за статистички значај постављен је на $\Pi \leq 0.05$.

\section{РЕЗУЛТАТИ}

Средња вредност \pm СД пре и после тренинга и разлике код рукометашица у шестонедељном плиометријском тренингу у предсезони у спринтевима, скоковима, анаеробној снази-капацитету и аеробним параметрима трчања при ФБЛЛ дате су у Табели 2. Сви подаци су нормално дистрибуирани и у тесту није откривено никакво нарушавање хомогености варијансе. У испитивањима пре тренинга, између ЕТГ и НТГ није било значајних разлика ни за једну варијаблу. 
Кале М., Утицаји шестонедељног плиометријског..., ФИЗИЧКА КУЛТУРА 2016; 70 (2): 145-154

Табела 2. Ефекти плиометријског тренинга на карактеристике перформанси рукометашица

\begin{tabular}{|c|c|c|c|c|c|c|c|c|}
\hline \multirow{2}{*}{\multicolumn{3}{|c|}{ Карактеристике перформанси }} & \multicolumn{3}{|c|}{ Пре } & \multicolumn{3}{|c|}{ После } \\
\hline & & & ETГ & НTГ & EC & ETГ & НТГ & EC \\
\hline \multirow{3}{*}{\multicolumn{2}{|c|}{ Скокови }} & $(\mathrm{cm})$ & $21.2 \pm 2.4$ & $21.0 \pm 2.6$ & 0.1 & $23.2 \pm 2.7^{\star}$ & $21.9 \pm 2.4^{\star}$ & 0.5 \\
\hline & & $\mathrm{MJ}(\mathrm{cm})$ & $23.0 \pm 2.2$ & $22.3 \pm 3.0$ & 0.3 & $25.9 \pm 2.7^{\star}$ & $24.0 \pm 2.3^{\star}$ & 0.8 \\
\hline & & $M J-S J_{\text {dif }}(\mathrm{cm})$ & $1.8 \pm 1.6$ & $1.3 \pm 1.3$ & 0.3 & $2.7 \pm 2.0$ & $2.2 \pm 1.6$ & 0.3 \\
\hline \multirow{3}{*}{\multicolumn{2}{|c|}{ Спринтеви }} & $\mathrm{m}(\mathrm{s})$ & $1.92 \pm 0.09$ & $1.93 \pm 0.08$ & 0.1 & $1.82 \pm 0.07^{\star *}$ & $1.80 \pm 0.09^{* *}$ & 0.3 \\
\hline & & $\mathrm{m}(\mathrm{s})$ & $3.41 \pm 0.14$ & $3.48 \pm 0.16$ & 0.5 & $3.30 \pm 0.14^{* *}$ & $3.29 \pm 0.15^{\star *}$ & 0.1 \\
\hline & & $\mathrm{m}(\mathrm{s})$ & $4.85 \pm 0.22$ & $4.93 \pm 0.26$ & 0.3 & $4.73 \pm 0.17^{\star \star}$ & $4.78 \pm 0.22^{\star *}$ & 0.3 \\
\hline \multirow{2}{*}{\multicolumn{2}{|c|}{$\begin{array}{l}\text { Капацитет } \\
\text { анаеробне моћи }\end{array}$}} & P (watt.kg-1) & $7.50 \pm 0.58$ & $6.80 \pm 0.79$ & 1.0 & $7.95 \pm 0.65^{*}$ & $7.34 \pm 1.01^{\star}$ & 0.7 \\
\hline & & $\mathrm{C}\left(\right.$ watt.kg $\left.{ }^{-1}\right)$ & $6.27 \pm 0.58$ & $5.82 \pm 0.51$ & 0.8 & $6.58 \pm 0.48^{\star}$ & $6.11 \pm 0.65$ & 0.8 \\
\hline \multicolumn{3}{|c|}{$\mathrm{VO}_{2} \max \left(\mathrm{kg} \cdot \mathrm{ml} \cdot \mathrm{min}^{-1}\right)$} & $49.1 \pm 2.1$ & $49.0 \pm 6.1$ & 0.1 & $51.5 \pm 2.0^{* *}$ & $50.5 \pm 5.3$ & 0.3 \\
\hline \multirow{3}{*}{\multicolumn{2}{|c|}{$2.0\left(\mathrm{mmol} \cdot \mathrm{l}^{-1}\right)$}} & $\mathrm{RV}\left(\mathrm{km} \cdot \mathrm{h}^{-1}\right)$ & $8.4 \pm 1.4$ & $8.0 \pm 1.8$ & 0.3 & $9.2 \pm 1.7^{\star \star}$ & $9.0 \pm 1.8$ & 0.1 \\
\hline & & HR (beats.min ${ }^{-1}$ ) & $154 \pm 13$ & $153 \pm 14$ & 0.1 & $158 \pm 13^{* *}$ & $157 \pm 9$ & 0.1 \\
\hline & & $\begin{array}{l}\mathrm{VO}_{2}(\mathrm{~kg} . \\
\left.\mathrm{ml} \cdot \mathrm{min}^{-1}\right)\end{array}$ & $34.4 \pm 5.7$ & $34.8 \pm 4.5$ & 0.1 & $39.5 \pm 6.4^{* *}$ & $38.7 \pm 7.8$ & 0.1 \\
\hline \multirow{9}{*}{ FBLLs } & \multirow{3}{*}{$3.0\left(\mathrm{mmol}^{-1} \mathrm{l}^{-1}\right)$} & $\mathrm{RV}\left(\mathrm{km} \cdot \mathrm{h}^{-1}\right)$ & $10.2 \pm 1.3$ & $10.1 \pm 1.6$ & 0.1 & $11.0 \pm 1.5^{\star *}$ & $10.6 \pm 1.9$ & 0.2 \\
\hline & & HR (beats.min ${ }^{-1}$ ) & $170 \pm 10$ & $171 \pm 12$ & 0.1 & $174 \pm 10^{*}$ & $173 \pm 11$ & 0.1 \\
\hline & & $\begin{array}{l}\mathrm{VO}_{2}(\mathrm{~kg} . \\
\left.\mathrm{ml} \cdot \mathrm{min}^{-1}\right)\end{array}$ & $41.4 \pm 3.7$ & $43.3 \pm 6.7$ & 0.4 & $46.6 \pm 4.2^{* *}$ & $44.5 \pm 6.9$ & 0.4 \\
\hline & \multirow{5}{*}{$4.0\left(\mathrm{mmol} \cdot \mathrm{l}^{-1}\right)$} & $\mathrm{RV}\left(\mathrm{km} \cdot \mathrm{h}^{-1}\right)$ & $11.4 \pm 1.1$ & $11.2 \pm 1.4$ & 0.2 & $12.1 \pm 1.1^{*}$ & $11.5 \pm 1.9$ & 0.4 \\
\hline & & HR (beats.min ${ }^{-1}$ ) & $178 \pm 9$ & $176 \pm 11$ & 0.2 & $183 \pm 9^{\star *}$ & $180 \pm 13$ & 0.3 \\
\hline & & $\begin{array}{l}\mathrm{VO}_{2}(\mathrm{~kg} . \\
\left.\mathrm{ml} \mathrm{min}^{-1}\right)\end{array}$ & $44.5 \pm 2.9$ & $46.3 \pm 6.3$ & 0.4 & $49.4 \pm 3.4^{* *}$ & $47.0 \pm 6.4$ & 0.5 \\
\hline & & $\mathrm{RV}\left(\mathrm{km} \cdot \mathrm{h}^{-1}\right)$ & $12.1 \pm 1.1$ & $12.0 \pm 1.4$ & 0.1 & $13.0 \pm 1.4^{* *}$ & $12.3 \pm 2.1$ & 0.4 \\
\hline & & HR (beats.min ${ }^{-1}$ ) & $186 \pm 9$ & $182 \pm 11$ & 0.4 & $190 \pm 10^{* *}$ & $187 \pm 16$ & 0.2 \\
\hline & $5.0\left(\mathrm{mmol} \cdot \mathrm{l}^{-1}\right)$ & $\begin{array}{l}\mathrm{VO}_{2}(\mathrm{~kg} . \\
\left.\mathrm{ml} \mathrm{min}^{-1}\right)\end{array}$ & $46.0 \pm 2.7$ & $49.0 \pm 6.1$ & 0.6 & $50.7 \pm 3.5^{\star *}$ & $50.5 \pm 5.3$ & 0.1 \\
\hline
\end{tabular}

Карактеристике испитаница су дате као $\mathrm{M} \pm \mathrm{CД}$. $\mathrm{ES}=$ ефекат величине. FBLLs = фиксни ниво лактата. Значајност разлика у односу на иницијално стање, ${ }^{*} \mathrm{p}<0.05,{ }^{* *} \mathrm{p}<0.01$. 
Оठе групе су показале значајне разлике пре и после тренинга у SJ и CMJ ( $<<0.05)$. Постоје мале и умерене EC разлике у SJ (ES=0.1), CMJ и CMJ$-\mathrm{SJ}_{\text {duf }}(\mathrm{ES}=0.3$, и $=0.3)$ између ЕТГ и НТГ у периоду пре тренинга. Умерене и велике ЕС разлике између ЕТГ и НТГ су уочене после тренинга код $\mathrm{SJ}$ и $\mathrm{CMJ}-\mathrm{SJ}_{\mathrm{duf}}(\mathrm{EC}=0.5$ и $=0.3)$, и $\mathrm{CMJ}(\mathrm{EC}=0.8)$. Оठе групе су показале значајне разлике пре и после тренинга у АР (p<0.05). ЕТГ је имала једину значајну разлику пре тренинга у односу на период после тренинга, и то у АС $(\mathrm{p}<0.05)$. Између ЕТГ и НТГ откривене су велике ЕС разлике у АР и $\mathrm{AC}$ пре тренинга $(\mathrm{EC}=1.0$ анд $=0.8)$, као и умерене и велике ЕС разлике после тренинга $(\mathrm{EC}=0.8$ и $=0.8)$. Постоји значајно смањење у спринтевима, укључујући $10 \mathrm{~m}, 20 \mathrm{~m}$ и $30 \mathrm{~m}(\mathrm{p}<0.01)$ пре и после тренинга у обе групе. Мале ЕС разлике у $10 \mathrm{~m}$ (ES $=0.1)$ и умерене $\mathrm{EC} \mathrm{разлике} \mathrm{у} 20 \mathrm{~m}$ и $30 \mathrm{~m}(\mathrm{EC}=$ 0.5$, и $=0.3)$ биле су присутне између ЕТГ и НТГ пре тренинга. Постојале су умерене ЕС разлике у $10 \mathrm{~m}$ и $30 \mathrm{~m}(\mathrm{ES}=0.3)$, и мале ЕС разлике у $20 \mathrm{~m}$ $(\mathrm{ES}=0.1)$ између ЕТГ и НТГ после тренинга. ЕТГ је показала значајне разлике пре и после тренинга у свим аеробним параметрима трчања при сваком FBLL (р између <0.01 и <0.05). ЕТГ је такође показала значајну промену у $\mathrm{VO}_{2} \max (\mathrm{p}<0.01)$ после тренинга у односу на период пре тренинга. Није било статистички значајних промена ни у једном аеробном параметру трчања при свим нивоима FBLL пре и после тренинга у групи НТГ. Постојале су мале и умерене ЕС разлике пре тренинга и после тренинга у аеробним парамтерима трчања $(0.1 \leq \mathrm{EC} \leq 0.6)$, између ЕТГ и НТГ.

\section{ДИСКУСИЈА}

У овом истраживању, циљ је био да се испитају утицаји шестонедељног плиометријског тренинга у предсезони на карактеристике перформанси рукометашица.

Откривене су значајне разлике у SJ и CMJ пре и после тренинга код ЕТГ и НТГ. Обе групе су повећале СЈ и ЦМЈ након тренинга. Нагано и сарадници (Nagano, Komura, \& Fukashiro, 2007) наводе да развијање максималне снаге помоћу тренинга са теговима, фокусирајући се на мишиће око зглоба колена уз обављање комбинованих тренинга скакања и учећи како да спортиста искористи те ојачане мишиће, побољшава перформансу скока код спортиста. У овој студији је приказано да су рукометашице биле оптерећене овом врстом тренинга у предсезони. Гери и сарадници (Gehri, Ricard, Kleiner, \& Kirkendall, 1998) су открили да способност скока развијена СМЈ тренингом обезбеђује контрактилну компоненту, пре него еластичну компоненту, услед повећане производње позитивне енергије. Због тога што пета не додирује подлогу одмах након доскока, спортиста треба да оствари оптимални учинак скока у односу на кратко време одраза. Марковић (Markovic, 2007) је истакао да је плиометријски тренинг побољшао SJ za 4.7\%. У односу на истраживање Марковића (Markovic, 2007), резултати ове студије имају другачије исходе. Тренинг у предсезони би могао бити разлог ових разлика због појединачних ефеката тренинга. Тренинг прогресивно интезивног скока или спринта може развити еластичност мишићног састава и тетива, као и потпорне структуре тела путем способности складиштења енергије (Elliott, Wagner, \& Chiu, 2007). Зато што се адаптација везивног ткива и повећање еластичности при овом снажном развоју мишића специфичном за спорт тренирају вежбама које унапређују “истегнуто скраћени циклус” (плиометријска контракција). Плиометријски тренинг је метода вежठања која користи истегнуто скраћени циклус и покрете скока. Малисоух и сарадници (Malisoux, Francaux, Nielens, \& Theisen. 2006) су открили повећање од $12 \%$ у мишићној снази и $13 \%$ у висини вертикалног скока након 8 недеља тренинга који је обухватао плиометријске скокове који утичу на истегнуто скраћени циклус перформансе вежठања. Боско и Коми (Bosco, \& Komi, 1979) наводе да је плиометријски тренинг оптерећење које се састоји од концентричних контракција након ексцентричног оптерећења и на тај начин доводи до рефлекса истезања, еластичности мишића, неуромускуларне адаптације Голџијевог тетивног органа (ГТО). Рефлекс истезања започиње у ексцентричној фази и тако помаже да се ангажује много више моторичких јединица у концентричној фази. Еластична енергија се чува у серијским и паралелним компонентама мишићно-везивног ткива. Када се ова сила брзо пренесе у концентричну фазу, ствара се додатна сила. ГТО има заштитну улогу против оптерећења укључујући додатну напетост у мишићима, међутим, Хатон и сарадници (Hutton \& Atwater, 1992) су истакли да плиометријски тренинг доводи до губитка 
сензације у ГТО и има потенцијал за превазилажење веће напетости у еластичним елементима мишића.

Трчање спринта је неуромускуларна карактеристика перформансе значајна за успех у врхунском женском рукомету (Wagner et al, 2014; Granados et al, 2007). Код врхунских рукометашица, откривена је веза између брзине трчања, силе и мишићне снаге мишића екстензора колена, што указује на могући трансфер из остварене мишићне снаге ногу у повећану перформансу спринта (Jensen et al, 1998). Спринт обухвата више зглобова и сегмената који су пажљиво координирани током сваке фазе става и захтева различиту интер и интрамускуларну координацију. Јанг и сарадници (Young, McDowell, \& Scarlett, 2001) су открили значајно повећање перформансе спринта на 30 м након шестонедељног тренинга спринта код искусних тимских спортиста. Чели и сарадници (Chelly, Hermassi, Aouadi, \& Shephard, 2014) наводе да осмонедељни плиометријски тренинг у сезони значајно мења брзине спринта на 0-5 m и 25-30 m. Наведене студије подржавају ово истраживање у томе да постоје значајне разлике пре и после тренинга у спринту на $10 \mathrm{~m}, 20 \mathrm{~m}$ и $30 \mathrm{~m}$ $(\mathrm{p}<0.01)$. Дакле, треба напоменути да је шестонедељни плиометријски тренинг у предсезони ефикасна тренажна метода за усавршавање трчања спринта код рукометаша. Кључно је то што рукометаши имају убрзање и могућност промене правца на кратким дистанцама.

ЕТГ и НТГ су показале значајне разлике пре и после тренинга у АР ( $<<0.05)$, али је једино ЕТГ показала значајну разлику у АC $(\mathrm{p}<0.05)$. Нема литературе која се односи на утицаје плиометријског тренинга на АР и АС код рукометашица, што нам дозвољава да направимо поређење. Међутим, резултати овог истраживања су показали да шестонедељни плиометријски тренинг у предсезони доприноси повећању АС.

Постојале су значајне разлике пре и после тренинга у ЕТГ групи у односу на параметре аеробне издржљивости укључујући RV, $\mathrm{HR}$ и $\mathrm{VO}_{2}$ при свим FBLL, поред $\mathrm{VO}_{2}$ max. Ове разлике, нарочито $\mathrm{VO}_{2}$ објашњавају да су се ефекти тренинга остварили. Јенсен и сарадници (Jensen et al., 1997) открили су да су вредности $\mathrm{VO}_{2}$ max код норвешких рукометашица пре тренинга износиле $51.3 \pm 2.3 \mathrm{ml} . \mathrm{kg}$. mиn $^{-1}$, а после тренинга $53.8 \pm 2.7 \mathrm{ml} . \mathrm{kg} \mathrm{mun}^{-1}$, док је ово истраживање показало да су вредности ВО-
${ }_{2}$ мах турских рукометашица пре тренинга износиле 49.0-49.1 ml.kg.mun ${ }^{-1}$, а после тренинга 50.551.5 ml.kg.mun ${ }^{-1}$. Иако су вредности $\mathrm{VO}_{2}$ max код Јенсена и сарадника (Jensen et al., 1997) биле веће него у овом истраживању, постоје слична повећања у овим двема студијама о ефектима тренинга. Као резултат ова два истраживања, може се тврдити да шестонедељни плиометријски тренинг током предсезоне позитивно доприноси аеробном капацитету рукометашица. Спортисти, на вишем нивоу $\mathrm{VO}_{2} \max$, показују боља постигнућа у ресинтетисању фосфокреатина након интермитентних тренинга високог интезитета (Tomlin, \& Wenger, 2001). Поред тога, плиометријски тренинг побољшава развој силе и снаге. Примена пажљиво програмираног плиометријског тренинга може имати потенцијално позитивне ефекте на аеробне варијабле тренинга издржљивости у RV, $\mathrm{HR}$, или $\mathrm{VO}_{2}$ при FBLL нивоима који одражавају регенерацију, екстензиван и интензиван темпо, екстезиван и интензиван интервал. Интервални тренинг скокова обухваћен традиционалним тренингом издржљивости доводи од умерених до великих утицаја на неуромускуларне и физиолошке параметре (Ache-Dias, Dellagrana, Teixeira, Dal Pupo, \& Moro, 2016) и може бити од суштинског значаја за побољшање перформанси рукометашица. Такође, обим тренинга и интензитет тренинга могу бити оријентисани.

\section{ЗАКЉУЧАК}

Тренинг у предсезони доводи до значајног повећања у погледу спринтева, чучањ скока и суножног скока, VO2max, RV, HR, као и $\mathrm{VO}_{2}$ при FBLL код рукометашица. Таква повећања ће се вероватно сматрати предностима јер ове био-моторичке карактеристике омогућавају спортистима јаке мишићне контракције, као и неопходну издржљивост за поједине акције у рукометној игри, као што су спринт, бацање лопте, блокирање, скакање, гурање и „шатл-ран“. Закључујемо да је шестонедељни плиометријски тренинг важан параметар, поред физичке спремности, техничког и тактичког тренинга, за рукометашице које се припремају за женску рукометну супер лигу, као и да утиче на карактеристике перформанси у предсезони. 


\section{REFERENCES}

1. Ache-Dias, J., Dellagrana, R.A., Teixeira, A.S., Dal Pupo, J., \& Moro, A.R. (2016). Effect of jumping interval training on neuromuscular and physiological parameters: a randomized controlled study. Applied Physiology, Nutrition and Metabolism, 41(1), 20-25.

2. Adams, K, O'Shea, J.P., O'Shea, K.L., \& Climstein, M. (1992). The effects of six weeks of squat, plyometrics, and squat plyometric training on power production. Journal of Applied Sport Science Research, 6, 36-41.

3. Bosco, C., \& Komi, P.V. (1979). Potentiation of the mechanical artifact of the human skeletal muscle through prestretching. Acta Physiologics Scandinavica, 106, 467-472.

4. Bosco, C., Luhtanen, P., \& Komi, P.V. (1983). A simple method for measurement of mechanical power in jumping. European Journal of Applied Physiology, 50, 273-282.

5. Vicente-Rodrigueza, G., Doradoa, C., PerezGomeza, J., Gonzalez-Henriquezbi, J.J., \& Calbet, J.A.L. (2004). Enhanced bone mass and physical fitness in young female handball players. Bone, 35 , 1208-1215.

6. Wagner, H., Finkenzeller, T., Wurth, S., \& von Duvillard, S.P. (2014). Individual and team performance in team-handball: a review. Journal of Sports Science \& Medicine, 13(4), 808-816.

7. Gehri, D.J., Ricard, M.D., Kleiner, D.M., \& Kirkendall, D.T. (1998). A comparison of plyometric training techniques for improving vertical jump ability and energy production. Journal of Strength \& Conditioning Research, 12(2), 85-89.

8. Gorostiaga, E.M., Granados, C., Ibanez, J., Gonzalez-Badillo, J.J., \& Izquierdo, M. (2006). Effects of an entire season on physical fitness changes in elite male handball players. Medicine \& Science in Sports \& Exercise, 38(2), 357-366.

9. Granados, C., Izquierdo, M., Ibanez, J., Bonnabau, H., \& Gorostiaga, E.M. (2007). Differences in physical fitness and throwing velocity among elite and amateur female handball players. International Journal of Sports Medicine, 28(10), 860-867.
10. Elliott, M.C.C.W., Wagner, P.P., \& Chiu, L. (2007). Power athletes and distance training: physiological and biomechanical rationale for change. Sports Medicine, 37(1), 47-57.

11. Inbar, O., Bar-Or, O., \& Skinner, J.S. (1996). The Wingate anaerobic test. Champaign, IL: Human Kinetics.

12. Janssen, P.G. (2001). Lactate threshold training. Champaign, IL: Human Kinetics.

13. Jensen, J., Jacobsen, S.T., Hetland, S., \& Tveit, P. (1997). Effect of combined endurance, strength and sprint training on maximal oxygen uptake, isometric strength and sprint performance in female elite handball players during a season. International Journal of Sports Medicine, 18, 354-358.

14. Young, W.B., McDowell, M.H., \& Scarlett, B.J. (2001). Specificity of sprint and agility training methods. Journal of Strength \& Conditioning Research. 15, 315-319.

15. Karcher, C., \& Bucheit, M. (2014). On-court demands of elite handball, with special reference to playing positions. Sports Medicine, 44(6), 797-814.

16. Malisoux, L., Francaux, M., Nielens, H., \& Theisen, D. (2006). Stretch-shortening cycle exercises: an effective training paradigm to enhance power output of human single muscle fibers. Journal of Applied Physiology, 100(3), 771-779.

17. Markovic, G. (2007). Does plyometric training improve vertical jump height? A meta-analytical review. British Journal of Sports Medicine, 41(6), 349-355.

18. Massuca, LM, Fragoso, I., \& Teles, J. (2014). Attributes of top elite team-handball players. Journal of Strength \& Conditioning Research, 28(1), 178-186.

19. Midgley, A.W ., McNaughton, L.R ., \& Caroll, S. (2007). Time at VO2max during intermittent treadmill running: test protocol dependent or methodological artifact? International Journal of Sports Medicine, 28(11), 934-939.

20. Nagano, A., Komura, T., \& Fukashiro, S. (2007). Optimal coordination of maximal-effort horizontal and vertical jump motions - a computer 
simulation study. BioMedical Engeneering OnLine, 6(20), 1-9.

21. Ronglan, L.T., Raastad, T., \& Børgese, A. (2006). Neuromuscular fatigue and recovery in elite female handball players. Scandinavian Journal of Medicine \& Science in Sport, 16, 267-273.

22. Smith, T.P., McNaughton, L.R., \& Marshall, K.J. (1999). Effects of 4-week training using Vmax/Tmax on VO2max and performance in athletes. Medicine \& Science in Sports \& Exercise, 31(6), 892-896.

23. Tomlin, D.L. \& Wenger, H.A. (2001). The relationship between aerobic fitness and recovery from high intensity intermittent exercise. Sport Medicine, 31(1), 1-11.

24. Hutton, R.S., \& Atwater, S.W. (1992). Acute and chronic adaptations of muscle proprioceptors in response to increased use. Sports Medicine, 14(6), 406-421.

25. Cavala, M., \& Katic, R. (2010). Morphological, motor and situation- motor characteristics of elite female handball players according to playing performance and position. Collegium Antropolgicum, 34(4), 1355-1361.

26. Chelly, M.S., Hermassi, S., Aouadi, R., \& Shephard, R.J. (2014). Effects of 8-week in-season plyometric training on upper and lower limb performance of elite adolescent handball players. Journal of Strength \& Conditioning Research, 28(5), 1401-1410.

27. Cohen, J. (1988). Statistical power analysis for the behavioral sciences. 2nd ed. Hillsdale, New Jersey: Lawrence Earlbaum Associates.

\title{
EINFLUSS EINES 6-WÖCHIGEN PLYOMETRISCHEN TRAININGS IN DER VORSAISON AUF PERFORMANCECHARAKTERISTIKEN VON HANDBALLSPIELERINNEN
}

\begin{abstract}
Zusammenfassung:
Ziel dieser Untersuchung war es, die Einflüsse eines 6-wöchigen plyometrischen Trainings in der Vorsaison auf die Charakteristiken der Performance von Handballspielerinnen festzustellen. An der Untersuchung nahmen auf freiwilliger Basis 19 Handballspielerinnen teil. Sie wurden in 2 Gruppen geteilt [(Experimentalgruppe (ETG) $(\mathrm{N}=10)$ und Kontrollgruppe (NTG) (N =9)]. Beide Gruppen trainierten regelmäßig in der Vorsaison während eines Zeitraums von 6 Wochen. Die Experimentalgruppe (ETG) hatte auch ein plyometrisches Training. Sprints $(10 \mathrm{~m}, 20 \mathrm{~m}$ und $30 \mathrm{~m})$, Sprung aus der Hocke (SJ), Absprung mit beiden Beinen (CMJ), anaerobe Ausdauer und Kapazität (AP und AC) sowie aerobe Variablen bei fixen Schwellen von Laktat im Blut (FBLL) [Laufgeschwindigkeit (RV), Puls (HR) und Sauerstoffverbrauch (VO2)] wurden vor und nach dem Training gemessen und verglichen. Die Ergebnisse zeigten bedeutende Unterschiede im SJ und CMJ ( $<<0,05)$, sowie bei allen Sprintarten $(\mathrm{p}<0,01)$, bei AP und AC $(\mathrm{p}<0.05), \operatorname{VO} 2 \mathrm{max}(\mathrm{p}<$ 0.01 ), RV, HR und VO2 bei jedem der FBLL $(\mathrm{p}<0.01$ ) vor und nach dem Training der Experimentalgruppe (ETG). Die Egebnisse vor und nach dem Training verweisen ebenfalls auf bedeutende Unterschiede bei SJ und CMJ $(\mathrm{p}<0.05)$, bei allen Sprintarten $(\mathrm{p}<0.01)$ und AP $(\mathrm{p}<0.05)$ in der Kontrollgruppe (NTG). Die Ergebnisse führen zur Schlussfolgerung, dass ein 6-wöchiges plyometrisches Training neben körperlicher Bereitschaft, technischem und taktischem Training einen wichtigen Parameter für die Charakteristiken der Performance in der Vorsaison bei Handballspielerinnen darstellen, die sich für die Superliga im Frauenhandball vorbereiten.
\end{abstract}

Schlüsselwörter: PLYOMETRISCHES TRAINING / SPRUNG / SPRINT / FIXE SCHWELLE VON LAKTAT IM BLUT

Примљен: 15.05.2016.

Прихваћен: 02.11.2016.

(c) 2016 Autor. Objavio Fizička kultura (www.fizickakultura.com). Ovo je članak otvorenog pristupa i distribuira se u skladu sa Creative Commons licencom (http://creativecommons.org/licenses/by/3.0/rs/). 